IZA DP No. 8242

Centralized vs. Decentralized Wage Formation:

The Role of Firms' Production Technology

Boris Hirsch

Christian Merkl

Steffen Mueller

Claus Schnabel

June 2014 


\title{
Centralized vs. Decentralized Wage Formation: The Role of Firms' Production Technology
}

\author{
Boris Hirsch \\ University of Erlangen-Nuremberg \\ Christian Merkl \\ University of Erlangen-Nuremberg, \\ Kiel Institute for the World Economy and IZA \\ Steffen Mueller \\ University of Erlangen-Nuremberg \\ and CESifo \\ Claus Schnabel \\ University of Erlangen-Nuremberg \\ and IZA \\ Discussion Paper No. 8242 \\ June 2014 \\ IZA \\ P.O. Box 7240 \\ 53072 Bonn \\ Germany \\ Phone: +49-228-3894-0 \\ Fax: +49-228-3894-180 \\ E-mail: iza@iza.org
}

Any opinions expressed here are those of the author(s) and not those of IZA. Research published in this series may include views on policy, but the institute itself takes no institutional policy positions. The IZA research network is committed to the IZA Guiding Principles of Research Integrity.

The Institute for the Study of Labor (IZA) in Bonn is a local and virtual international research center and a place of communication between science, politics and business. IZA is an independent nonprofit organization supported by Deutsche Post Foundation. The center is associated with the University of Bonn and offers a stimulating research environment through its international network, workshops and conferences, data service, project support, research visits and doctoral program. IZA engages in (i) original and internationally competitive research in all fields of labor economics, (ii) development of policy concepts, and (iii) dissemination of research results and concepts to the interested public.

IZA Discussion Papers often represent preliminary work and are circulated to encourage discussion. Citation of such a paper should account for its provisional character. A revised version may be available directly from the author. 


\section{ABSTRACT}

\section{Centralized vs. Decentralized Wage Formation: The Role of Firms' Production Technology}

This paper is the first to show theoretically and empirically how firms' production technology affects the choice of their preferred wage formation regime. Our theoretical framework predicts, first, that the larger the total factor productivity of a firm, the more likely it is to opt for centralized wage formation where it can hide behind less productive firms. Second, the larger a firm's scale elasticity, the higher its incentive to choose centralized rather than decentralized wage setting due to labor cost and straitjacket effects. As firms in Germany are allowed to choose their wage formation regime, we test these two hypotheses with representative establishment data for West Germany. We find that establishments with centralized bargaining agreements indeed have economically and statistically significantly larger total factor productivities and scale elasticities than comparable establishments outside the centralized bargaining regime.

JEL Classification: $\quad J 50$

Keywords: collective bargaining, bargaining coverage, Germany

Corresponding author:

Claus Schnabel

University of Erlangen-Nuremberg

Chair of Labour and Regional Economics

Lange Gasse 20

90403 Nuremberg

Germany

E-mail: claus.schnabel@fau.de

\footnotetext{
"We would like to thank Christian Haefke, Jörg Lingens, and Dennis Snower for useful suggestions. We further appreciate the comments received from seminar participants in Kiel, Nuremberg, and Würzburg.
} 


\section{Introduction}

Although collective bargaining at different levels is the predominant wage formation mechanism in most continental European and various other countries, the economic rationale for alternative bargaining regimes is not fully understood yet. From a macroeconomic perspective, Calmfors and Driffill (1988) show in a seminal paper that centralized wage bargaining agreements may internalize various types of externalities that arise from decentralized wage setting at firm level since bargaining parties at central level cannot escape negative macroeconomic effects such as unemployment (see also Danthine and Hunt, 1994). If the gains from such an internalization are sufficiently large, centralization will emerge as the preferred wage-setting arrangement (for a review of this strand of literature, see Flanagan, 2003). Boeri and Burda (2009) argue from an institutional perspective that in countries with larger firing costs collective bargaining agreements rather than decentralized wage setting may be the preferred option for a large share of workers and firms. But why is it that in a country with the same institutions applying to all actors some firms choose to be part of a centralized collective bargaining agreement while others do not? A number of papers have tried to interpret the preferred level of wage setting as an explicit decision by individual firms, taking into account various aspects such as transaction costs, asymmetric information, flexibility in work organization and pay, dampening competition by imposing similar wages, and power factors (see, e.g., Ramaswamy and Rowthorn, 1993, Freeman and Gibbons, 1995; Lindbeck and Snower, 2001; Arrowsmith et al., 2003; Zagelmeyer, 2004). In this microeconomic perspective, those firms for which the advantages of decentralization (such as tailoring wages to the specific situation of the firm, higher employer bargaining power, and increased firm flexibility) outweigh the amenities of traditional centralized bargaining (such as lower transaction costs and taking wages out of competition) opt for decentralized wage setting at the firm level (Schnabel et al. 2006).

Our paper contributes to the literature by offering new theoretical hypotheses how heterogeneous production technology across firms affects their choice for centralized or decentralized wage formation. In our theoretical model (Section 2), we argue that firms 
with larger total factor productivity and larger scale elasticities are ceteris paribus more likely to opt for centralized wage formation. We assume that the centralized wage does not react to firm-specific outcomes but is rather based on some industry average or some other aggregate reference point. This allows us to show three theoretical effects which affect firms' choice of the optimal wage formation regime. First, under centralized wage formation firms with larger total factor productivity have the possibility to hide behind the sector-level average ("hide effect"). Thus, those firms' profitability increases compared to decentralized wage formation. $]^{1}$ Second, for a given wage (e.g. determined by centralized wage formation) a firm with a lower scale elasticity faces larger labor costs per unit of production ("labor cost effect"). Thus, a lower scale elasticity makes it more likely that firms prefer decentralized over centralized wage formation, as the former takes this lower scale elasticity into account. Third, while all previous effects have been derived in a pure static environment, there is an additional dynamic effect. When firms are subject to aggregate fluctuations and face some short-run price rigidity, scale elasticities matter even more $2^{2}$ A smaller scale elasticity means that firms face a steeper marginal cost curve (in terms of firm-specific output). With steeper marginal costs, centralized wage formation may form a straitjacket ("straitjacket effect") because it does not allow firm-specific wage adjustments. ${ }^{3}$

The "straitjacket effect" becomes very intuitive when comparing a constant returns to scale firm to a decreasing returns firm. The constant returns firm faces marginal costs that are independent of the production quantity. Thus, even under uncertainty, it has a constant mark-up over the centralized wage. By contrast, the decreasing returns firm faces an upward-sloping marginal cost curve. Thus, under centralized wage formation, the firm

1 Boeri and Burda s 2009) model hypothesizes that firms which employ workers in the upper part of the skill distribution would prefer the collective bargaining agreement. Although the outcome of Boeri and Burda's and our model may be observationally equivalent under some circumstances, the economic rationale is very different. In addition, we provide an empirical test and condition on the skill composition of firms' workforces.

2 For evidence in favor of short-run price rigidities in the Euro zone, see for example Altissimo et al. (2006).

3 This result is complementary to the theoretical results by Jimeno and Thomas (2013) who show that sectoral-level bargaining agreements and the associated wage compression lead to higher unemployment. In contrast to us, Jimeno and Thomas use a search and matching model with idiosyncratic shocks and do not model different production technologies explicitly. 
may become unprofitable when hit by a firm-specific demand shock. This is not the case under decentralized wage formation where the wage adjusts to firm-specific marginal cost fluctuations. Similar to the labor cost effect, the straitjacket effect makes it more likely for firms with lower scale elasticities to opt for decentralized wage formation.

Thus, our simple theoretical model unambiguously predicts that firms with larger total factor productivity and larger scale elasticities are ceteris paribus more likely to opt for centralized bargaining. We argue that German institutions offer an exceptional case for testing these theoretical hypotheses (Section 3). German labor law allows firms to choose whether they want to be part of a centralized collective bargaining agreement or not, and we present evidence that although a large number of firms are covered by multi-employer agreements at sectoral level, many firms prefer wage setting at the firm level.

We put our theory to the test with data from the IAB Establishment Panel (Section 4), a representative annual survey of about 16,000 German establishments with information on firms' bargaining status as well as on revenues/value added, labor input, and investment. Fixed-effects estimations of production functions for the period 1996 to 2010 confirm our two theoretical hypotheses. First, establishments which are covered by centralized bargaining agreements at sectoral level have substantially larger scale elasticities, i.e. the estimated sum of the coefficients of a Cobb-Douglas production function is economically and statistically significantly different from that of establishments which choose some local arrangement at firm level (either firm-level bargaining or individual wage setting). Second, establishments with a larger total factor productivity are significantly more likely to be covered by centralized bargaining.

Our results are important for several reasons. Our simple theoretical framework (supported by the empirical evidence for Germany) is the first to offer a systematic and intuitive answer for how production technologies and wage formation mechanisms interact..$^{4}$ Furthermore, since in Germany firms may choose their preferred bargaining

4 That (changes in) work organization and technology may play a role for collective bargaining agreements has been noted before. See, e.g., Lindbeck and Snower (2001) who stress the increasing importance of multi-tasking favoring decentralized wage setting. Ortigueira $(2013)$ argues that equipment-specific technical progress and equipment-skill complementarity combined with the unemployment benefit program have affected centralized wage bargaining in Sweden. 
regime (and thus opt out of centralized bargaining as recommended by Jimeno and Thomas, 2013), this provides interesting policy-relevant insights for other countries where opting out of the centralized wage formation regime is not possible (yet). Our work suggests that opting out is particularly important for firms and sectors with low total factor productivity and low scale elasticities.

\section{Theoretical Model}

We provide a model that allows us to analyze firms' rationale to determine wages on the centralized or decentralized level. We assume that firms are heterogeneous in terms of their production functions (i.e. they differ in terms of the total factor productivity and the scale elasticity) and that the production function is fixed for a firm's entire life span. Thus, technology is a primitive of the economy and impossible to change for an existing firm. There are various reasons why heterogeneous firms with different production functions (e.g. high and low productivity firms) may coexist, such as segmented submarkets, deviations from perfect competition on the product market, convex costs of attracting additional workers, or overhead costs that increase convexly with firm size. However, a detailed general equilibrium analysis of the coexistence and entry/exit of different technology firms is beyond the scope of our paper. Instead, we analyze the rationale of firms with different production technologies to join the centralized bargaining agreement from a pure partial equilibrium perspective. Afterwards, we analyze empirically whether the coexistence of these different firms can be found in the data and whether the chosen bargaining regimes follow the patterns predicted by our model.

Suppose a firm producing a good from its homogenous labor input with $q(n)=a n^{\alpha}$, where $0<\alpha \leq 1$ denotes its scale elasticity and $a$ its total factor productivity. $5^{5}$ To produce some quantity $q$, it thus needs labor input $n(q)=(q / a)^{1 / \alpha}$ and pays labor costs $w n(q)$, where $w$ is the wage paid by the firm. With respect to the wage paid by the firm we consider two polar cases: Either the firm is covered by a centralized bargaining

$5 \quad$ It is straightforward to include capital as a second production factor in this model, though doing so complicates exposition. For expository simplicity, we will therefore stick to the simple case with labor as the single factor of production here and sketch the more general model in Appendix A. 
agreement, or wages are set decentrally at the firm level (by negotiating with a union or directly with employees). Under centralized bargaining, the wage is some fixed $\bar{w}$. The underlying assumption is that the firm is small relative to the entire sector. Thus, the centralized wage does not react to firm-specific variations. In the opposite polar case, under decentralized wage setting the wage is pinned down at the firm's marginal revenue product of labor $w(q)=(1-1 / \eta) p q^{\prime}(n(q))=(1-1 / \eta) p \alpha a n(q)^{\alpha-1}$ with $\eta \equiv-q^{\prime} p / q$ denoting the price elasticity of the firm's demand.6

Assume next that there are fixed transaction costs, which may be functions of firms' observable characteristics, that differ in both regimes with the transaction costs under centralized bargaining being lower than under decentralized wage setting, $T_{C}<T_{D}$. The firm's total costs is therefore the sum of total labor costs and transaction costs. So the firm's cost functions under centralized bargaining $C_{C}(q)$ or decentralized wage setting $C_{D}(q)$, respectively, are:

$$
\begin{cases}C_{C}(q)=\bar{w}\left(\frac{q}{a}\right)^{1 / \alpha}+T_{C} & \text { (centralized bargaining) } \\ C_{D}(q)=\left(1-\frac{1}{\eta}\right) p \alpha q+T_{D} & \text { (decentralized wage setting) }\end{cases}
$$

Note that the cost function under centralized bargaining is strictly convex and thus exhibits increasing marginal costs if the firm's production technology is subject to decreasing returns to scale, i.e. $\alpha<1$, whereas it is linear under decentralized wage setting no matter what the firm's returns to scale are.

Consider now the choice of the firm whether to join a centralized bargaining agreement. Let us start with the case where firms are not subject to any type of aggregate or idiosyncratic uncertainty. For a given firm-specific output, the firm will join an agreement iff its costs under centralized bargaining are lower than under decentralized wage setting, i.e. $\left.C_{C}(q)<C_{D}(q)\right]^{7}$ In other words, the firm will opt for centralized bargaining iff the

$6 \quad$ As a relaxation to this extreme case we could also think of firm-level bargaining rather than individual wage setting with the firm's wage $\tilde{w}(q)$ being responsive to its output level where $w^{\prime}(q)<\tilde{w}^{\prime}(q)<\bar{w}^{\prime}(q)=0$. In any case we would have a firm-level wage decreasing in the firm's output, which is actually all that is needed for the following reasoning to hold.

7 Obviously, the optimal firm-specific output is not independent of the wage formation regime. For illustration purposes, we show our results for a given output. The effects would be augmented, 
savings in transaction costs from bargaining centrally are larger than the associated rise in labor costs from doing so. Using (1) we thus arrive at

$$
T_{D}-T_{C}>\bar{w}\left(\frac{q}{a}\right)^{1 / \alpha}-\left(1-\frac{1}{\eta}\right) p \alpha q
$$

Our core question now is: How does the decision for centralized bargaining depend on firms' production technology? We assume that firms differ in production technology in terms of the scale elasticity $\alpha$ and total factor productivity $a$. To arrive at unambiguous results, we will abstract from the (empirically uninteresting and irrelevant) case with $q / a=n^{\alpha}<1$, i.e. $n<1$, and thus impose that firms employ at least one worker. In the following, we will distinguish three different effects of production technology on firms' decision to join centralized bargaining which we term (i) the "hide effect", (ii) the "labor cost effect", and (iii) the "straitjacket effect".

First, consider firms differing in their total factor productivity $a$. If $a$ increases, this reduces a firm's labor costs under centralized bargaining (i.e. the first term on the righthand side of (2) ) and centralized bargaining becomes more attractive, ceteris paribus. The reason for this is that the centralized wage does not depend on this single firm's productivity level but is set outside the firm reflecting some weighted average of the productivities of the firms inside the centralized bargaining agreement ${ }^{8}$ It therefore allows a high-productivity firm to hide behind the centralized wage, whereas under decentralized wage setting this firm's wage would directly reflect its productivity. According to this "hide effect", there is a threshold value $\tilde{a}$, and all firms with $a>\tilde{a}$ join the centralized bargaining agreement while all firms with $a \leq \tilde{a}$ opt for firm-level wage setting $\left.\right|^{9}$

though, when considering output differences under different wage formation regimes. Assume a firm for which the decentralized regime is optimal and which produces $q_{D}$ in this regime. If it were forced to switch to centralized wage formation, it would produce some output $q_{C}<q_{D}$. Under monopolistic competition on the product market, firms set their price as a mark-up over marginal costs. Thus, a reduction of the output reduces overall profits and renders the centralized wage formation regime even less favorable.

8 We are agnostic on how the wage $\bar{w}$ in the sectoral agreement emerges. The crucial assumption needed for our argument to hold is that the centralized wage depends less on a single firm's productivity than the wage under decentralized wage setting. For Germany, Gürtzgen (2009) provides empirical evidence that centralized wage bargaining is associated with a lower responsiveness of wages to firm-specific conditions than local wage setting.

9 Although we are probably the first to formally model this "hide effect", the possibility of hiding behind a centralized agreement oriented towards the less productive (and usually smaller) firms in 
Second, turn to heterogeneities in the other dimension of the production technology, namely differences in the scale elasticity $\alpha$. If $\alpha$ decreases, the labor costs under centralized bargaining rise (i.e. the first term on the right-hand side of (2p) and the labor costs under decentralized bargaining fall (i.e. the second term on the right-hand side of (2)) so that centralized bargaining becomes less attractive, ceteris paribus. These two reactions reflect that (i) under centralized bargaining the firm's cost function becomes more convex thereby raising labor costs while (ii) under decentralized wage setting the firm's marginal revenue product and thus its wage drop thereby lowering labor costs. According to this "labor cost effect", a lower scale elasticity renders centralized bargaining more costly relative to decentralized wage setting.

Third, when additionally allowing for fluctuating output, there is also a "straitjacket effect" related to the convexity of the firm's cost function under centralized bargaining and decreasing returns to scale, i.e. $\alpha<1$, adding to the "labor cost effect". To show this, assume that firms face mean-zero random demand shocks and that their output price is fixed at some level $\bar{p} \cdot{ }^{10}$ Due to the convexity of the cost function, i.e. increasing marginal costs, demand fluctuations raise expected costs under centralized bargaining. We therefore get

$$
\mathrm{E}\left[C_{C}(q)\right]>C_{C}(\mathrm{E}[q])=C_{C}(q)
$$

where increases in expected costs become more pronounced if the scale elasticity $\alpha$ is lower. In other words, the lower is $\alpha$, the steeper is the firm's marginal cost curve under centralized bargaining and the more costly fluctuating demand gets. On the other hand, expected costs stay constant under decentralized wage setting because the cost function

an industry has been recognized before in the industrial relations literature (see, e.g., Kohaut and Schnabel, 2003). In a case study of a large firm in the German metalworking industry, Arrowsmith et al. (2003) report that the firm is committed to centralized bargaining because it feels that the powerful metalworkers' union would achieve more when bargaining at the firm level.

10 For expositional simplicity, we choose fixed prices as a shortcut here. In Appendix B, we demonstrate that the same conclusions hold under price rigidities as those generated by Taylor contracts. 
is linear in this case,

$$
\mathrm{E}\left[C_{D}(q)\right]=C_{D}(\mathrm{E}[q])=C_{D}(q)
$$

In a nutshell, the "straitjacket effect" states that centralized bargaining agreements put additional costs on firms when coping with firm-specific fluctuating demand. As the "straitjacket effect" adds to the "labor cost effect" and is magnified by more fluctuating demand, under sufficient demand fluctuations we arrive at a threshold value for the scale elasticity $\tilde{\alpha}$ with all firms with $\alpha>\tilde{\alpha}$ opting for centralized bargaining and all firms with $\alpha \leq \tilde{\alpha}$ for firm-level wage setting.

Taken together, we can derive the following two hypotheses. (i) We expect firms opting for centralized bargaining to show a higher average scale elasticity for two reasons: The higher is the scale elasticity, the flatter is the marginal cost curve under centralized bargaining and the cheaper centralized bargaining gets ("labor cost effect"); and the flatter the marginal cost curve, the less likely it is that a centralized bargaining agreement becomes a straitjacket under fluctuating firm-level demand ("straitjacket effect"). (ii) We expect firms opting for centralized bargaining to have a higher average total factor productivity. This holds because centralized bargaining is more attractive for highproductivity firms as the bargained wage reflects some weight of productivities of those firms within the agreement ("hide effect"). These two hypotheses will be tested with German establishment data in Section 4. As firms' transactions costs cannot be directly observed and are likely to depend on many factors, our empirical strategy will employ a fixed-effects estimator controlling for time-invariant unobserved firm heterogeneity on top of controls for observables.

\section{Institutional Background}

In Germany, the constitutionally protected principle of bargaining autonomy gives (organizations of) employers and employees the right to regulate wages and working conditions without state interference. Firms have three options for wage setting: First, 
they may apply collective agreements negotiated at sectoral level between employers associations and trade unions. While these sectoral negotiations mostly take place in regional bargaining districts, the regional negotiations within one sector are closely coordinated by the officials of the appropriate sectoral trade union and employers association, so that variations between them are small. Collectively agreed norms are minimum terms, which means that firms covered by collective agreements cannot undercut upon these terms and conditions (unless specifically allowed to do so in "opening clauses" for cases of emergency). Second, firms may conduct bargaining at firm level with a union (but not with a works council), resulting in a firm-specific agreement. Collective agreements at firm or sectoral level are legally binding and they are usually applied to the entire workforce in a firm or sector, not only to union members. Third, firms may decide not to make use of collective bargaining and rather lay down their wages and working conditions in labor contracts settled individually with employees.

In terms of our theoretical model, the first option (i.e. a collective agreement at sectoral level) is equivalent to centralized collective bargaining that does not take account of firm characteristics and conditions. Options 2 and 3 represent two ways of decentralized wage formation, by negotiating either with a union or directly with employees, which both enable firms to tailor wages and working conditions to their specific economic situation. Note that even if a strong union and a heavily unionized workforce coerce a firm to conclude a collective agreement, the firm is still free to choose either a sector-level or a firm-level agreement, in such a way opting for centralized or decentralized wage setting. In contrast, even if its workforce is not heavily unionized (yet) a highly productive and profitable firm may choose to join a centralized collective agreement and hide there in order to avoid that its workforce starts unionizing and extracting firm-specific rents.

The presence and coverage of these three bargaining regimes in our sample are shown in Table 1 based on information on West Germany from the representative IAB Establishment Panel described below ${ }^{11}$ It can be seen that in 2010, the final year of

11 We concentrate on West Germany since post-communist East Germany has a completely different history of wage formation where the state was setting wages and no collective or individual bargaining was possible. Related to this, it is unclear whether the transformation process of East Germany from a socialist planned economy to a market economy was completed in the early years covered by our 
our investigation, sectoral-level collective agreements applied in about 33 percent of establishments in the private sector, covering 53 percent of employees. Coverage rates of employees are higher than those of establishments since larger plants are more likely to make use of sectoral collective bargaining. Single-employer collective agreements at firm level were found in just 2 percent of establishments, employing about 7 percent of workers. 65 percent of plants and 40 percent of employees were not covered by a collective agreement, which means that their wages and working conditions were laid down in individual contracts. Coverage rates are a little bit higher in manufacturing which will be in the focus of our empirical analysis. These numbers indicate that unlike the situation in the US or the UK, collective bargaining in Germany is still mainly conducted at the sectoral level (although wage setting at the firm level is gaining ground) ${ }^{12}$

Table 1: Collective bargaining coverage in West Germany (percentage of establishments and employees covered in 2010)

\begin{tabular}{lcccccc}
\hline $\begin{array}{l}\text { Establishment } \\
\text { size interval } \\
\begin{array}{l}\text { (number } \\
\text { of employees) }\end{array}\end{array}$ & $\begin{array}{c}\text { Sector-level } \\
\text { collective agreement } \\
\text { Private } \\
\text { Sector }\end{array}$ & $\begin{array}{c}\text { Manu- } \\
\text { facturing }\end{array}$ & $\begin{array}{c}\text { Frivate } \\
\text { collective agreement } \\
\text { Sector }\end{array}$ & $\begin{array}{c}\text { Manu- } \\
\text { facturing }\end{array}$ & $\begin{array}{c}\text { No collective } \\
\text { agreement } \\
\text { Sector }\end{array}$ & $\begin{array}{c}\text { Manu- } \\
\text { facturing }\end{array}$ \\
\hline Less than 50 & 31.3 & 31.6 & 1.8 & 1.7 & 66.9 & 66.7 \\
50 to 199 & 53.4 & 38.7 & 8.2 & 8.5 & 38.4 & 52.9 \\
200 and above & 66.5 & 65.7 & 10.6 & 12.6 & 22.9 & 21.8 \\
\hline All establishments & 32.6 & 33.4 & 2.2 & 2.7 & 65.2 & 63.9 \\
All employees & 52.6 & 56.7 & 7.4 & 10.8 & 40.0 & 32.5 \\
\hline
\end{tabular}

Notes: The data set used is the 2010 wave of the IAB Establishment Panel, own calculations using weighted data.

data. Even today bargaining coverage is substantially lower in East than in West Germany (see Ellguth and Kohaut, 2012).

12 For a comparison and analysis of collective bargaining structures in Germany and Britain, see Schnabel et al. (2006). 


\section{Empirical Analysis}

\subsection{Data}

We use the IAB Establishment Panel provided by the Institute for Employment Research (Institut für Arbeitsmarkt- und Berufsforschung, IAB) of the German Federal Employment Agency (Bundesagentur für Arbeit) ${ }^{13}$ This is a representative sample of plants (not companies) that employ at least one worker covered by social security at the 30th June of a year and comprises all sectors of the German economy. Each year since 1993 (1996), the IAB Establishment Panel has surveyed several thousand plants in West (East) Germany. Response rates of plants which have been interviewed repeatedly exceed 80 percent. The data are collected on the basis of a questionnaire and personal interviews with the owner or managers. We will use information on the number of workers, value added (defined as sales minus the costs of intermediate inputs), capital stock, workforce composition, coverage by sectoral or firm-level collective wage agreements, works council existence, the plant's age and legal status, being a single plant, and exporting activity. ${ }^{14}$

As information on collective bargaining coverage is fragmentary in the earlier panel waves, we use data encompassing the years 1996 to 2011. Each wave of interviews provides retrospective information on value added in the previous year. Hence, we run our regressions for the years 1996 to 2010. To end up with a sample of comparable plants (in terms of production technology, industrial relations, and the interpretation of value added), we focus on manufacturing plants only. Table 2 shows definitions and descriptive statistics for plants making use of centralized sector-level bargaining or of decentralized local bargaining (comprising firm-level agreements and no collective agreements).

\subsection{Returns to Scale}

We test our first hypothesis that plants covered by centralized bargaining agreements have larger scale elasticities by running some standard productivity regressions. To estimate

\footnotetext{
13 Details about the data are given by Kölling $(2000)$ and Ellguth et al. $(2014)$.

14 Capital stock is approximated using the approach outlined in Mueller $(2008,2010)$.
} 
Table 2: Descriptive statistics for the regression sample

\begin{tabular}{lrrrr}
\hline & \multicolumn{2}{c}{$\begin{array}{c}\text { Centralized } \\
\text { bargaining }\end{array}$} & \multicolumn{2}{c}{$\begin{array}{c}\text { Decentralized } \\
\text { wage formation }\end{array}$} \\
Variable description & Mean & St.dev. & Mean & St.dev. \\
\hline Log value added & 15.84 & 2.26 & 14.75 & 1.87 \\
Log employment & 4.90 & 1.83 & 3.98 & 1.56 \\
Log capital stock & 15.70 & 2.52 & 14.46 & 2.15 \\
Percentage of skilled workers & 62.48 & 22.68 & 57.57 & 25.55 \\
Percentage of part-time workers & 8.75 & 12.69 & 12.62 & 16.30 \\
Percentage of apprentices & 4.88 & 6.04 & 4.00 & 5.57 \\
Young plant (<5 years) & 0.02 & 0.15 & 0.05 & 0.21 \\
Single plant & 0.63 & 0.48 & 0.82 & 0.38 \\
Limited Liability & 0.79 & 0.40 & 0.79 & 0.41 \\
Exporter & 0.66 & 0.48 & 0.63 & 0.48 \\
\hline Observations & \multicolumn{2}{c}{7,452} & & 4,946 \\
\hline
\end{tabular}

Notes: The data set used is the IAB Establishment Panel, 1996-2010. Establishments are West German manufacturing plants.

returns to scale, we use the regression

$$
\log y_{i t}=\beta_{1} \log n_{i t}+\beta_{2} \log k_{i t}+\mathbf{x}_{i t}^{\prime} \boldsymbol{\gamma}+a_{i}+e_{t}+\varepsilon_{i t}
$$

where $y_{i t}$ denotes the value added of firm $i$ in period $t, n_{i t}$ its total employment, and $k_{i t}$ its capital stock. Since log employment and log capital enter (5) linearly, we arrive at a CobbDouglas specification. Furthermore, $\mathbf{x}_{i t}$ is a vector of controls comprising the percentages of skilled workers, part-time workers, and apprentices, $a_{i}$ is a plant fixed effect, $e_{t}$ is a year fixed effect, and $\varepsilon_{i t}$ is the idiosyncratic error component.

The panel character of our data allows us to take unobserved time-invariant plant heterogeneity into account, such as differences in management quality. To get rid of any biases that may stem from such heterogeneity, we estimate equation (5) using a fixedeffects within estimator. This estimator uses deviations from the within plant mean of all variables to identify regression parameters. The major advantage of this procedure is 
that the plant fixed effect cancels out so that any correlation between $a_{i}$ and explanatory variables will not bias results. We removed all plants that have been observed only once during our observation period.

Table 3: Returns to scale from fixed-effects regressions

\begin{tabular}{|c|c|c|c|}
\hline Establishment & \multicolumn{2}{|c|}{ Bargaining regime } & \multirow[b]{2}{*}{ Decentralized } \\
\hline (\# employees) & All & Centralized & \\
\hline All & $\begin{array}{c}0.75^{*} \\
{[0.70,0.79]}\end{array}$ & $\begin{array}{c}0.85^{*} \\
{[0.78,0.92]}\end{array}$ & $\begin{array}{c}0.63^{*} \\
{[0.56,0.70]}\end{array}$ \\
\hline Less than 50 & $\begin{array}{c}0.57^{*} \\
{[0.51,0.64]}\end{array}$ & $\begin{array}{c}0.61^{*} \\
{[0.50,0.72]}\end{array}$ & $\begin{array}{c}0.57^{*} \\
{[0.47,0.66]}\end{array}$ \\
\hline 50 to 199 & $\begin{array}{c}0.79^{*} \\
{[0.71,0.88]}\end{array}$ & $\begin{array}{c}0.82^{*} \\
{[0.68,0.95]}\end{array}$ & $\begin{array}{c}0.81^{*} \\
{[0.68,0.91]}\end{array}$ \\
\hline 200 and above & $\begin{array}{c}0.96 \\
{[0.87,1.04]}\end{array}$ & $\begin{array}{c}1.00 \\
{[0.90,1.09]}\end{array}$ & $\begin{array}{c}0.45^{*} \\
{[0.22,0.68]}\end{array}$ \\
\hline \multicolumn{4}{|c|}{$\begin{array}{l}\text { Notes: The data set used is the IAB Establishment Panel, 1996-2010. } \\
\text { Establishments are West German manufacturing plants. Results are based } \\
\text { on equation } 5 \text { and control variables include year dummies and the } \\
\text { percentages of skilled workers, part-time workers, and apprentices. * } \\
\text { denotes statistically significant differences to constant returns to scale at } \\
\text { the } 5 \text { percent level. } 95 \text { percent confidence intervals are shown in brackets. }\end{array}$} \\
\hline
\end{tabular}

Table 3 presents estimates of plants' returns to scale (i.e. $\left.\beta_{1}+\beta_{2}\right)$ in the manufacturing sector for subsamples of plants distinguished by bargaining coverage and plant size. As can be seen from the first row of Table 3 , plants covered by centralized bargaining have higher returns to scale than those with decentralized wage formation. Plants' scale elasticity is 0.85 under centralized bargaining but just 0.63 under decentralized wage formation (i.e. under firm-level agreements or individual bargaining) ${ }^{15}$ As confidence intervals do not overlap, we regard this difference as statistically significant. In line with our theoretical expectations, firms covered by centralized bargaining have higher returns to scale and

15 We are not the first to find decreasing returns to scale for German plants. Also applying a fixed-effects estimator within a Cobb-Douglas framework for the manufacturing sector but using a different data set, Harhoff (1998) finds scale elasticities around 0.73 (see the coefficients of $\log (L)$ in his Table 3 ). We also acknowledge the possibility that measurement error might have attenuated our coefficient estimates and, therefore, the estimated level of scale elasticities for both bargaining regimes. However, since our theory only requires us to find a difference in scale elasticities across regimes, the level effect of measurement error is unlikely to play much a role here. 
thus flatter marginal cost curves than firms with decentralized wage formation. As the further rows of Table 3 make clear, this finding holds true for all plant size categories though differences between wage formation regimes are only statistically significant for large plants with at least 200 employees. To scrutinize our results, we further performed some checks of robustness. Our results are qualitatively the same when excluding (i) the crisis years 2009 and 2010, (ii) plants belonging to multi-plants firms, and (iii) small plants with no more than ten employees ${ }^{16}$

\subsection{Total Factor Productivity}

In a next step, we test whether plants with a higher total factor productivity are more likely to be covered by centralized bargaining, as suggested by our second hypothesis. We estimate a probit model regressing an indicator for being covered by such an agreement on the estimated plant fixed effect $a_{i}$ from equation (5) reflecting plant $i$ 's total factor productivity ${ }^{17}$ As controls we include various standard variables found to matter for firms' wage formation regime in earlier studies (see Schnabel et al., 2006; Addison et al., 2013): plant size, workforce composition (percentages of skilled and part-time workers as well as apprentices), plant age, being part of a multi-plant firm, legal form, exporter status, and two-digit industry.

As Table 4 presenting average partial effects makes clear, plants with larger total factor productivity are indeed significantly more likely to be covered by centralized bargaining. In line with theory, a 10 percent larger total factor productivity is associated with a 1.1 percentage points larger probability of such an agreement when not controlling for other determinants of plants' wage formation regime (model 1). When we include the variables found to be associated with centralized bargaining in previous studies, these controls are statistically highly significant (model 2). Even then, the average partial effect of an increase in total factor productivity by 10 percent still amounts to 0.4 percentage points and is statistically significant at the 5 percent level. This suggests that productivity is an

$16 \quad$ Detailed results are available on request.

17 Interpreting the fixed effect $a_{i}$ as plant $i$ 's total factor productivity is standard in the literature on plant productivity. Of course we are aware that differences in plants' fixed effects may also reflect unobserved differences in output prices (Griliches and Mairesse, 1999). 
additional, hitherto neglected factor associated with plants' choice of a wage formation mechanism.

Table 4: Probit regression for the probability of being covered by centralized bargaining

\begin{tabular}{|c|c|c|}
\hline & Model 1 & Model 2 \\
\hline \multirow[t]{2}{*}{ Total factor productivity } & $0.113^{* *}$ & $0.037^{*}$ \\
\hline & $(0.011)$ & $(0.016)$ \\
\hline \multirow[t]{2}{*}{ 50-199 employees } & - & $0.062^{*}$ \\
\hline & & $(0.026)$ \\
\hline \multirow[t]{2}{*}{ At least 200 employees } & - & $0.226^{* *}$ \\
\hline & & $(0.032)$ \\
\hline \multirow[t]{2}{*}{ Percentage of skilled workers } & - & $0.001^{* *}$ \\
\hline & & $(0.000)$ \\
\hline \multirow[t]{2}{*}{ Percentage of part-time workers } & - & $-0.003^{* *}$ \\
\hline & & $(0.001)$ \\
\hline \multirow[t]{2}{*}{ Percentage of apprentices } & - & $0.007^{* *}$ \\
\hline & & $(0.001)$ \\
\hline \multirow[t]{2}{*}{ Young plant $(<5$ years $)$} & - & $-0.110^{* *}$ \\
\hline & & $(0.029)$ \\
\hline \multirow[t]{2}{*}{ Single plant } & - & $-0.118^{* *}$ \\
\hline & & $(0.021)$ \\
\hline \multirow[t]{2}{*}{ Limited liability } & - & $-0.082^{* *}$ \\
\hline & & $(0.022)$ \\
\hline \multirow[t]{2}{*}{ Exporter } & - & $-0.107^{* *}$ \\
\hline & & $(0.021)$ \\
\hline Dummies for 15 sectors & - & $\checkmark$ \\
\hline Observations & \multicolumn{2}{|c|}{12,398} \\
\hline
\end{tabular}

Notes: The data set used is the IAB Establishment Panel, 1996-2010. Establishments are West German manufacturing plants. The dependent variable is 1 if the plant is covered by a sector-level collective agreement and 0 otherwise. Total factor productivity is the estimated plant fixed effect from regression model (5). Reported numbers are average partial effects. $* * / *$ denotes statistical significance at the $1 / 5$ percent level. Standard errors are clustered at the plant level. 


\section{Conclusions}

Our paper has provided a partial equilibrium perspective on firms' optimal choice of the wage formation regime. We show, first, that the more productive a firm, the larger is the incentive to opt for centralized wage formation. The reason is that centralized wages will be based on the average industry productivity or some other reference group but not on firm-specific productivity. Thus, highly productive firms can hide behind less productive firms and thus increase their profitability ("hide effect"). Second, the smaller the scale elasticity of a firm, the larger is the incentive to opt for decentralized wage formation. For a given wage, a firm with lower scale elasticities faces larger labor costs per unit of production, ceteris paribus ("labor cost effect"). In contrast, under decentralized wage formation larger marginal costs will lead to a lower wage, and decentralization gets more attractive for the firm. Third, under fluctuating demand and some form of short-run price rigidity, there is an additional "straitjacket effect". Due to the convexity of marginal costs under decreasing returns, demand fluctuations raise the (intertemporal) average costs and more so the lower the scale elasticity.

Our simple model provides some new answers to the long-standing question why within a country some firms choose to be part of a centralized bargaining agreement while others do not. A typical example is Germany where labor law allows firms to choose their preferred wage formation mechanism, offering a unique opportunity to check our hypotheses with German data. Fixed-effects estimations of production functions for establishments with different wage formation choices show that establishments that are covered by centralized sector-level agreements have significantly larger scale elasticities than establishments that opted for decentralized wage formation. In addition, we find that plants with a larger total factor productivity are more likely to be covered by a bargaining agreement at sectoral level, ceteris paribus. Both patterns are consistent with our model's hypotheses and suggest that production technology is an additional, previously overlooked determinant of firms' choice of a wage bargaining regime.

Although there exist quite a few macroeconomic, microeconomic, and institutional explanations of alternative wage setting regimes that are not fundamentally questioned 
by our insights, economists so far know relatively little about the interaction of firms' production technology and wage formation mechanisms. Our paper has come up with a simple theory and documented some new and interesting facts. We are the first to provide a formal theoretical connection between production technology and the preferred wage formation regime and to document the corresponding empirical patterns. Although our data and research design do not allow us to identify causal relationships, our findings may serve as a starting point for future research. From a theoretical perspective, the model framework can certainly be extended (e.g. from a partial to a general equilibrium framework, including free entry of firms). We expect our key theoretical insights to be unaffected. From an empirical perspective, it is certainly of interest whether similar patterns can be found in other countries, particularly those where the process of wage formation has considerably changed over time (e.g. the UK) or has been reformed recently (e.g. Spain). 


\section{Appendices}

\section{A Endogenous Capital}

Other than in our simplified model discussed in Section 2, suppose now that a firm is producing a homogenous good from both its capital and labor inputs and that it chooses its capital stock optimally. For our argument given above to hold, it suffices to show (i) that a constant returns to scale (CRS) firm has constant marginal costs under both centralized bargaining and firm-level wage formation and (ii) that a decreasing returns to scale (DRS) firm has increasing marginal costs under centralized bargaining and constant marginal costs under firm-level wage formation. Then, the rest of our argument follows mutatis mutandis.

Assume the firm's production technology is $q(n, k)=a n^{\alpha} k^{\beta}$ with $\alpha+\beta=1$ in the CRS case and $\alpha+\beta<1$ in the DRS case with $k$ denoting the capital stock. If capital is chosen optimally, such that the interest rate $i$ equals the marginal revenue product of capital $(1-1 / \eta) p q_{k}(n, k)$, we have

$$
k(n)=\left(\frac{(1-1 / \eta) p \beta a n^{\alpha}}{i}\right)^{\frac{1}{1-\beta}}
$$

With capital chosen optimally the output produced thus gets

$$
q(n) \equiv q(n, k(n))=\theta a^{\frac{1}{1-\beta}} n^{\frac{\alpha}{1-\beta}}
$$

with $\theta \equiv[(1-1 / \eta) p \beta / i]^{\frac{\beta}{1-\beta}}$. Hence, the labor input needed to produce $q$ is

$$
n(q)=\left(\frac{q}{\theta a^{\frac{1}{1-\beta}}}\right)^{\frac{1-\beta}{\alpha}}
$$

As the interest rate is pinned down at the marginal revenue product of capital, total capital costs are $i k(n(q))=q_{k}[n(q), k(n(q))] k(n(q))=(1-1 / \eta) p \beta q$. Under centralized bargaining with some fixed wage $\bar{w}$ the firm's labor costs are $\bar{w} n(q)$. Thus, the firm's cost 
function is

$$
C(q)=\bar{w}\left(\frac{q}{\theta a^{\frac{1}{1-\beta}}}\right)^{\frac{1-\beta}{\alpha}}+(1-1 / \eta) p \beta q .
$$

So the firm's cost function inhibits increasing marginal costs under DRS with $\alpha+\beta<1$ and constant marginal costs under CRS with $\alpha+\beta=1$.

If instead the wage is pinned down at the marginal revenue product of labor with $w(q)=(1-1 / \eta) p q_{n}[n(q), k(n(q))]=(1-1 / \eta) p \alpha \theta a^{\frac{1-\beta}{\beta}} n(q)^{\frac{\alpha+\beta-1}{1-\beta}}$, total labor costs are $w(q) n(q)=(1-1 / \eta) p \alpha \theta a^{\frac{1-\beta}{\beta}} n(q)^{\frac{\alpha}{1-\beta}}=(1-1 / \eta) p \alpha q$. Thus, the firm's cost function is

$$
C(q)=(1-1 / \eta) p(\alpha+\beta) q
$$

with constant marginal costs independently of the firm's returns to scale. Thus, the argument presented in Section 2 readily extends to the case of endogenous capital.

\section{B Price Rigidities}

Although the presence of price rigidities is widely documented (see, e.g., Bils and Klenow, 2004, or Altissimo et al., 2006), the underlying causes are not well understood yet. Thus, the macroeconomic literature uses shortcuts to implement a realistic degree of price rigidity into the models (according to Calvo, 1983, Rotemberg, 1982, or Taylor, 1980). Up to a first-order Taylor approximation, all three shortcuts deliver the same aggregate dynamics. For illustration purposes, we assumed in Section 2 that prices are fixed at some given level. We show below that this is the case for a certain fraction of firms in an economy with Taylor contracts. These firms face larger average costs under demand fluctuations when they have a decreasing returns technology.

According to Taylor (1980) firms set prices for some periods in advance in overlapping manner. For illustration purposes, we choose the simplest case where one half of the firms sets their prices in one period and the other half sets them in the other period. Firms which set prices in the current period know the realization of the aggregate (and idiosyncratic 
shocks). But they face uncertainty about next period's realizations, although they make an unbiased forecast under rational expectations.

Firms act under monopolistic competition subject to a CES demand function, i.e. the firm-specific demand is equal to $q_{i t}=\left(p_{i t}^{*} / p_{t}\right)^{-\eta} q_{t}$, where $q_{t}$ refers to aggregate demand, $p_{t}$ refers to the aggregate price level, and $p_{i t}^{*}$ to the optimal price in period $t$. Thus, the price setting problem of firms which can adjust their prices is

$$
\begin{aligned}
\max \pi_{t}=p_{i t}^{*} & \left(\frac{p_{i t}^{*}}{p_{t}}\right)^{-\eta} q_{t}-w_{i t}\left(q_{i t}\right)\left[\left(\frac{p_{i t}^{*}}{p_{t}}\right)^{-\eta} q_{t}\right]^{1 / \alpha}+\delta p_{i t}^{*} \mathrm{E}_{t}\left(\frac{p_{i t}^{*}}{p_{t+1}}\right)^{-\eta} q_{t+1} \\
& -\delta \mathrm{E}_{t} w_{i, t+1}\left(q_{i, t+1}\right)\left[\left(\frac{p_{i t}^{*}}{p_{t+1}}\right)^{-\eta} q_{t+1}\right]^{1 / \alpha},
\end{aligned}
$$

where $\delta$ is the discount factor and $\mathrm{E}_{t}$ is the expectations operator under rational expectations. The firm maximizes the intertemporal discounted profits subject to the monopolistic competition and the price rigidity.

We focus on the centralized bargaining case with $w_{i t}\left(q_{i t}\right)=\bar{w}_{t}$ and $w_{i t}^{\prime}\left(q_{i t}\right)=0$. Thus,

$$
\begin{aligned}
\frac{\partial \pi_{t}}{\partial p_{i t}^{*}}=( & -\eta)\left(p_{i t}^{*}\right)^{-\eta} p_{t}^{\eta} q_{t}+\frac{\eta}{\alpha}\left(p_{i t}^{*}\right)^{-\frac{\eta-\alpha}{\alpha}} \bar{w}_{t}\left(p_{t}^{\eta} q_{t}\right)^{1 / \alpha}+(1-\eta)\left(p_{i t}^{*}\right)^{-\eta} \delta \mathrm{E}_{t} p_{t+1}^{\eta} q_{t+1} \\
& +\frac{\eta}{\alpha}\left(p_{i t}^{*}\right)^{-\frac{\eta-\alpha}{\alpha}} \delta \mathrm{E}_{t} \bar{w}_{t+1}\left(p_{t+1}^{\eta} q_{t+1}\right)^{1 / \alpha}=0
\end{aligned}
$$

The optimal price then is given by

$$
p_{i t}^{*}=\left(\frac{\eta}{(\eta-1) \alpha} \frac{\bar{w}_{t}\left(p_{t}^{\eta} q_{t}\right)^{1 / \alpha}+\delta \mathrm{E}_{t} \bar{w}_{t+1}\left(p_{t+1}^{\eta} q_{t+1}\right)^{1 / \alpha}}{p_{t}^{\eta} q_{t}+\delta \mathrm{E}_{t} p_{t+1}^{\eta} q_{t+1}}\right)^{\frac{\alpha}{\alpha+\eta(1-\alpha)}}
$$

This optimal price takes into account the contemporaneous realization of the variables (namely the wage, the aggregate price level, and aggregate demand) and rational expectations about future realizations of the variables.

Although prices were set optimally in period $t$, firms are subject to demand fluctuations under rigid prices in period $t+1$. Under centralized bargaining, the cost function in period 
$t+1$ is

$$
C_{t+1}\left(q_{i, t+1}\right)=\bar{w}_{t+1}\left[\left(\frac{p_{i t}^{*}}{p_{t+1}}\right)^{-\eta} q_{t+1}\right]^{1 / \alpha} .
$$

Thus, with $0<\alpha<1$ firms face a convex cost structure $\left(C^{\prime}>0, C^{\prime \prime}>0\right)$ under centralized bargaining, and the argument presented in Section 2 extends to an environment where firms act under monopolistic competition and Taylor contracts. 


\section{References}

Addison, J.T., Bryson, A., Teixeira, P., Pahnke, A., and Bellmann, L. (2013), 'The extent of collective bargaining and workplace representation: Transistions between states and their determinants. A comparative analysis of Germany and Great Britain,' Scottish Journal of Political Economy, 60(2):182-209.

Altissimo, F., Bilke, L., Levin, A., Mathä, T., and Mojon, B. (2006), 'Sectoral and aggregate inflation dynamics in the Euro area,' Journal of the European Economic Association (Papers and Proceedings), 4(2/3):585-593.

Arrowsmith, J., Marginson, P., and Sisson, K. (2003), 'Externalisation and internalisation of collective bargaining in Europe: Variation in the role of large companies,' Industrielle Beziehungen, 10(3):363-392.

Bils, M. and Klenow, P.J. (2004), 'Some evidence on the importance of sticky prices,' Journal of Political Economy, 112(5):947-985.

Boeri, T. and Burda, M.C. (2009), 'Preferences for collective versus individualised wage setting,' Economic Journal, 119(540):1440-1463.

Calmfors, L. and Driffill, J. (1988), 'Bargaining structure, corporatism and macroeconomic performance,' Economic Policy, 3(6):13-61.

Calvo, G.A. (1983), 'Staggered prices in a utility-maximizing framework,' Journal of Monetary Economics, 12(3):383-398.

Danthine, J.P. and Hunt, J. (1994), 'Wage bargaining structure, employment and economic integration,' Economic Journal, 104(424):528-541.

Ellguth, P. and Kohaut, S. (2012), 'Tarifbindung und betriebliche Interessenvertretung: Aktuelle Ergebnisse aus dem IAB-Betriebspanel 2011,' WSI-Mitteilungen, 65(4):297-305.

Ellguth, P., Kohaut, S., and Möller, I. (2014), 'The IAB Establishment Panel - methodological essentials and data quality,' Journal for Labour Market Research, 47(1/2):27-41.

Flanagan, R.J. (2003), 'Collective bargaining and macroeconomic performance,' in J.T. Addison and C. Schnabel (eds.), 'International Handbook of Trade Unions,' pp. 172-196, Cheltenham: Edward Elgar.

Freeman, R.B. and Gibbons, R.S. (1995), 'Getting together and breaking apart: The decline of centralized collective bargaining,' in R.B. Freeman and L.F. Katz (eds.), 'Differences and Changes in Wage Structures,' pp. 345-370, Chicago and London: University of Chicago Press.

Griliches, Z. and Mairesse, J. (1999), 'Production functions: The search for identification,' in S. Strøm (ed.), 'Econometrics and Economic Theory in the 20th Century: The Ragnar Frisch Centennial Symposium,' pp. 169-203, Cambridge: Cambridge University Press. 
GüRTzGEn, N. (2009), 'Rent-sharing and collective bargaining coverage: Evidence from linked employer-employee data,' Scandinavian Journal of Economics, 111(2):323-349.

HARHOFF, D. (1998), 'R\&D and productivity in German manufacturing firms,' Economics of Innovation and New Technology, 6(1):29-50.

Jimeno, J.F. and Thomas, C. (2013), 'Collective bargaining, firm heterogeneity and unemployment,' European Economic Review, 59(1):63-79.

Kohaut, S. and Schnabel, C. (2003), 'Zur Erosion des Flächentarifvertrags: Ausmaß, Einflussfaktoren und Gegenmaßnahmen,' Industrielle Beziehungen, 10(2):193-219.

KÖLling, A. (2000), 'The IAB-Establishment Panel,' Schmollers Jahrbuch, 120(2):291300.

LindBeck, A. and SNower, D.J. (2001), 'Centralized bargaining and reorganized work: Are they compatible?' European Economic Review, 45(10):1851-1875.

Mueller, S. (2008), 'Capital stock approximation using firm level panel data: A modified perpetual inventory approach,' Journal of Economics and Statistics, 228(4):357-371.

(2010), Capital stock approximation with the perpetual inventory method: Stata code for the IAB Establishment Panel, Institut für Arbeitsmarkt- und Berufsforschung, Nuremberg, FDZ Methodenreport No. 02/2010.

Ortigueira, S. (2013), 'The rise and fall of centralized wage bargaining,' Scandinavian Journal of Economics, 115(3):825-855.

Ramaswamy, R. and Rowthorn, R.E. (1993), Centralized bargaining, efficiency wages, and flexibility, International Monetary Fund, Washington, DC, IMF Working Paper No. 93/25.

Rotemberg, J.J. (1982), 'Monopolistic price adjustment and aggregate output,' Review of Economic Studies, 49(4):517-531.

Schnabel, C., Zagelmeyer, S., and Kohaut, S. (2006), 'Collective bargaining structure and its determinants: An empirical analysis with British and German establishment data,' European Journal of Industrial Relations, 12(2):165-188.

TAYLOR, J.B. (1980), 'Aggregate dynamics and staggered contracts,' Journal of Political Economy, 88(1):1-23.

Zagelmeyer, S. (2004), Governance Structures and the Employment Relationship, Berne and Oxford: Peter Lang. 